\title{
Subklinik Mastitis’in Anadolu Mandalarının Süt Kompozisyonundaki Bazı Biyokimyasal Parametrelere Etkisi
}

\author{
Hande Gürler' ${ }^{1}$ Gülay Çiftci², Seçkin Salar³, Ayhan Baştan ${ }^{3}$ \\ ${ }^{1}$ Ondokuz Mayls Üniversitesi, Veteriner Fakültesi, Klinik Bilimler Anabilim Dall, Samsun \\ ${ }^{2}$ Ondokuz Mayls Üniversitesi, Veteriner Fakültesi, Biyokimya Anabilim Dal, Samsun \\ ${ }^{3}$ Ankara Üniversitesi, Veteriner Fakültesi Doğum ve Jinekoloji Anabilim Dall, Ankara
}

Geliş Tarihi / Received: 25.05.2018, Kabul Tarihi / Accepted: 17.10.2018

\begin{abstract}
Özet: Bu araştırmada, subklinik mastitisli Anadolu mandalarının süt serumunda bazı biyokimyasal değerlerin araştırılması amaçlandı. Çalışma materyalini, on adet sağlıklı ve altı adet sublinik mastitisli olduğu belirlenen manda sütleri oluşturdu. Sağlıklı ve mastitisli manda sütleri, Kaliforniya Mastitis Testi (CMT) ve somatik hücre sayısı (SHS)'ye göre belirlendi. Alınan sütlerin serumunda albümin, total protein, trigliserit, üre ve ürik asit düzeyi analizör cihazında belirlendi. Somatik hücre sayısı yüksek olan ( $\mathrm{SHS}>429 \times 10^{3}$ hücre $/ \mathrm{mL}$ ) subklinik mastitisli mandaların süt serumu sağlıklı manda süt serumu ile karşılaştırıldığında albümin düzeyinin önemli düzeyde $(\mathrm{P}<0.05)$ yüksek olduğu total protein ve üre düzeyinin ise hafif düzeyde arttığı belirlendi $(\mathrm{P}>0.05)$. Trigliserit düzeyinin ise mastitisli manda sütünde sağlıklı manda sütüne göre önemli düzeyde $(\mathrm{P}<0.05)$, ürik asit düzeyinin ise hafif düzeyde azaldığı saptandı ( $\mathrm{P}>0.05)$. Somatik hücre sayısı ile albümin, total protein ve üre arasında pozitif korelasyon olduğu, trigliserit ve ürik asit arasında ise negatif bir korelasyon olduğu belirlendi. Bu sonuçlar ile laboratuvar bulgularının klinik bulgular ile birlikte subklinik mastitisi anlamada yardımcı olabileceği, tanısal ve prognostik olarak kullanılabileceği kanısına varılmıştır.
\end{abstract}

Anahtar Kelimeler: Manda, Subklinik Mastitis, Süt

\section{The Effect of Subclinical Mastitis on Some Biochemical Parameters in Milk Composition of Anatolian Water Buffalos}

\begin{abstract}
Summary: In this study, it was aimed to investigate some biochemical values in milk serum of subclinical mastitic Anatolian buffaloes. The study material consisted of ten healthy and six buffaloes identified as having subclinical mastitis. Healthy and mastitic buffalo milks were determined by the California Mastitis Test (CMT) and somatic cell count (SCC). Albumin, total protein, triglyceride, urea and uric acid levels were determined in the serum of the receiving milk samples in the analyzer. When the milk serum of the subclinical mastitis with high somatic cell count (SCC $>429 \times 103$ cells / $\mathrm{mL}$ ) was compared with healthy buffaloe's milk serum, it was found that the albumin level was increased significantly $(\mathrm{P}<0.05)$ and total protein and urea levels were slightly increased $(\mathrm{P}>0.05)$. Triglyceride levels were found to be significantly $(\mathrm{P}<0.05)$ lower in the mastitic buffalo than in the healthy buffalo $(\mathrm{p}<0.05)$, while uric acid level decreased slightly $(\mathrm{P}>0.05)$. There was a positive correlation between SCC and albumin, total protein and urea, and a negative correlation between triglyceride and uric acid. These results suggested that laboratory findings may be helpful in the diagnosis of subclinical mastitis in conjunction with clinical findings, and may be used as diagnostic and prognostic indicators.
\end{abstract}

Key Words: Buffalo, Milk, Subclinical Mastitis

\section{Giriş}

Mastitis, meme bezinin irritanlara karşı reaksiyonu olup meme dokusunu, süt kalite ve miktarını önemli ölçüde etkileyen ekonomik açıdan önemli bir hastalıktır $[8,49]$. Mastitis'in çeşitli nedenleri ve şiddet dereceleri vardır. Subklinik mastitis, klinik yönden fark edilebilen ancak, lokal ve sistemik belirti göstermeden seyreden ve sütte lökosit sayısında artışa neden olan, patojen etkenlerin izolasyonu ve bazı biyokimyasal değişimlerin belirlenmesi ile tanınabilen mastitis türüdür [30]. Hastalık, sütün yapısında değişikliklere neden olmakta ve mastitis kaynaklı süt üretim kayıplarının \%70-80'i subklinik mastitisten kaynaklanmaktadır [16]. Klinik mastitisin tedavisi zor olup, subklinik mastitis düzeyinde belirlenebilmesinin önemli olduğu bildirilmiştir [43]. Subklinik mastitis teşhisinde kimyasal ve mikrobiyolojik birçok test kullanılmaktadır [9,43]. Son yıllarda somatik hücre sayısı (SHS)'nın belirlenmesini esas alan testler gittikçe önem kazanmaktadır. Somatik hücreler, meme bezinin enfeksiyon yada 
hasarlanmasına yanıt olarak bölgeye gelen, memedeki sekretorik epitelleri dejenere eden mikroorganizmalar ile mücadele ederken ölen ve sütün içine karışan akyuvarlardır. Sütteki somatik hücrelerin $\% 75$ 'ini lökosit, \%25'ini de epitel hücreler oluşturmaktadır [13].

Sütün içeriğini başlıca su, yağ, laktoz ve protein oluşturur. Manda sütünün protein, laktoz, yağ ve kuru madde içeriği inek sütünden çok daha yüksektir [2]. Sütün içerisinde en çok bulunan protein kazein olup albümin ve globülin daha az miktardadır. Meme içi enfeksiyon, subklinik olsa bile, süt verimini ve içeriğini etkilemektedir [15]. Subklinik mastitis kazein olmayan protein konsantrasyonunun artışına neden olmaktadır. Bu artışın daha çok kan serum albümin ve immunoglobülin artışından kaynaklanabileceği bildirilmiştir [17]. Sütteki yağ, meme epitel hücrelerinde yağ damlacıkları olarak salgılanmaktadır. Yağ damlacıkları fosfolipit ve kolesterolden oluşan trigliserit yapıda bir zar ile çevrilidir. Trigliseritler toplam süt yağının yaklaşık \%97-98'ini oluşturmaktadır. Trigliseritler süt alveol hücresine ait endoplazmik retikulumların dış yüzeyinde, gliserol ve yağ asitlerinden sentezlenmektedir. Manda sütünün yağ oranı inek sütünden yaklaş1k olarak iki kat daha fazla, enerji ve besin değeri daha yüksektir [45]. Mastitisin meydana gelmesi yağ konsantrasyonunu etkilemektedir. Bu durumun meme bezinin yapisından veya sekresyon kapasitesinin azalmasından kaynaklanabileceği belirtilmektedir [33].

Üre dokulardaki proteinlerin katabolizması sonucu oluşan, kan ve vücut sıvılarında bulunan organik bir moleküldür. Hayvanların yetersiz miktarda protein alması halinde özellikle bağırsaklardan emilmektedir. Üre aynı zamanda pirimidin katabolizması sonucu oluşmaktadır [37]. Sütteki üre seviyeleri, süt kompozisyonu, cins, mevsim, somatik hücre sayısı, beslenme rejimi, besleme yöntemi, beslenme süresi, kuru madde tüketimi gibi birçok faktöre bağlı olarak değişmektedir [28,34]. Sütteki üre düzeyinin kan plazmasındaki üre düzeyi ile güçlü bir ilişkisi vardır [21]. Süt ve kandaki üre konsantrasyonun, süt ineklerinin beslenmesindeki enerji ve proteini izlemek için önemli bir parametre olduğu bildirilmiştir [18]. Üre düzeyinin sütte belirlenmesinin kan alma sırasında oluşan stresi önlediğ $i$ ve daha pratik olduğu bildirilmiştir [10]. Süt üre nit- rojen değerinin ineklerin sağlığı ve beslenmesiyle ilgili bilgiler sağlaması nedeniyle sürü sağlı̆̆ ve besleme ekonomisi açısından önemli olduğu ve rasyondaki karbonhidrat ve protein arasındaki dengeyi yansıttığı belirtilmiştir [6].

Ürik asit, plazma antioksidan kapasitesine önemli ölçüde katkıda bulunan, iyi bilinen bir antioksidandır. Alveol epitel hücrelerinde üretilir ve daha sonra süte salınır [25].

$\mathrm{Bu}$ çalışmada, SHS ile subklinik mastitis olduğu belirlenen Anadolu mandalarının süt komposizyonundaki total protein, albümin, trigliserit, üre ve ürik asit düzeylerine olan etkisinin belirlenmesi amaçlanmıştır.

\section{Materyal ve Metot}

Çalışmanın materyalini Samsun ilinde yetiştirilen, 10 adet sağlıklı ve 6 adet subklinik mastitisli oldugu belirlenen Anadolu mandalarından alınan sütler oluşturdu.

\section{California Mastitis Testi}

Mandalardan toplanan sütlerde subklinik mastitis olgusu California Mastitis Testi (CMT) analiz edildi. CMT sonuçları Schalm ve ark.,'nın [36]. tarif ettiği yönteme göre yapıldı.

\section{Süt serumu çıkarılması}

Alınan sütler 15000 g 15dk santrifüj edilerek yağ tabakası ayrılarak süpernatant çıkarıldı. Biyokimyasal analizler elde edilen bu süpernatanttan gerçekleştirildi [19].

\section{Biyokimyasal parametreler}

Süt serumlarında albümin, total protein, trigliserit, üre ve ürik asit düzeyleri Biosistem kitleri kullanılarak otoanalizör (Biosistem A25, İspanya) cihazında ölçüldü.

\section{İstatistiksel değerlendirme}

İstatistiksel analizler için SPSS (SPSS-PC, SPSS Inc., Chicago, Illinois, USA) kullanıldı. Verilerin analizinde bağımsız örneklemler için T-testi ve tek yönlü varyans analizi (ANOVA) testi ve gruplar arasındaki ilişkiyi belirlemek için Pearson korelasyon testi uyguland. 


\section{Bulgular}

Sağlıklı Anadolu manda sütlerinde ortalama SHS 27.1 \pm 3.9 olarak belirlendi. Somatik hücre sayıs1 $429 \times 10^{3}$ hücre/mL'den büyük olan sütler subklinik mastitis pozitif olarak kabul edildi. Subklinik mastitisli manda sütlerinde SHS ortalaması ise $1529.66 \pm 547.05$ olarak belirlendi. Subklinik mastitisli olan Anadolu Manda sütlerinde SHS'deki artışın istatistiksel olarak önemli olduğu belirlendi $(\mathrm{P}<0,001)$ (Tablo 1).

Subklinik mastitisli ve sağlıklı manda süt serumundaki albümin, total protein, trigliserit, üre ve ürik asit düzeyinin ortalaması ve standart hata değerleri tablo1'de sunulmuştur.

Subklinik mastitisli mandaların süt serumunda albümin düzeyinin sağl1klı manda sütüne göre istatistiksel olarak anlamlı düzeyde arttığı $(\mathrm{P}<0.05)$, total protein ve üre düzeyinin ise subklinik mastitisli olan mandalarda sağlıklı olan manda sütlerine göre arttığı ama bu artışın istatistiksel olarak önemli olmadı $\breve{g}_{1}(\mathrm{P}>0.05)$ belirlendi.

Subklinik mastitisli mandaların süt serumunda trigliserit düzeyinin sağlıklı manda süt serumuna göre önemli düzeyde azaldığı $(\mathrm{P}<0.05)$, ürik asit düzeyinin ise hafif düzeyde azaldı $\breve{g}_{1}$ belirlendi $(\mathrm{P}>0.05)$.

Tablo 1. Subklinik mastitisli ve sağlık manda sütlerindeki, somatik hücre sayısı (SHS), albümin, total protein, trigliserit, üre ve ürik asit düzeyleri (ortalama \pm SE)

\begin{tabular}{lccc}
\hline & Sağlıklı grup & Mastitisli grup & P \\
\hline Albümin (g/dl) & $2.7 \pm 0.15$ & $7.33 \pm 1.72$ & 0,021 \\
Total Protein(g/dl) & $1.16 \pm 0.22$ & $2.03 \pm 0.37$ & 0,425 \\
Trigliserit (mg/dl) & $53.9 \pm 10.27$ & $37.16 \pm 3.48$ & 0,003 \\
Üre (mg/dl) & $28.2 \pm 1.91$ & $35 \pm 3.23$ & 0,51 \\
Ürik asit (mg/dl) & $1.37 \pm 0.15$ & $0.94 \pm 0.23$ & 0,428 \\
SHS & $27.1 \pm 3.9$ & $1529.66 \pm 547.05$ & 0 \\
\hline
\end{tabular}

SHS, albümin, total protein, trigliserit, üre ve ürik asit düzeyleri arasındaki korelasyon ilişkisi tablo 2'de sunulmuştur.

SHS ile ürik asit arasında önemli düzeyde negatif korelasyon $\left(\mathrm{r}=-0.649^{* *}\right)$ olduğu SHS ile albümin arasında önemli düzeyde pozitif korelasyon $\left(\mathrm{r}=0.786^{* *}\right)$ olduğu belirlendi.
Total protein, albümin ve üre arasında önemli düzeyde pozitif korelasyon olduğu belirlendi

$\left(\mathrm{r}=0.772 * *, \mathrm{r}=0.731^{* *}\right)$. Aynı şekilde trigliserit ile ürik asit düzeyi arasında da pozitif korelasyon $(\mathrm{r}=0.439)$ olduğu belirlendi. Üre ve ürik asit arasında ise negatif korelasyon ( $r=-0.457)$ olduğu saptandi.

Tablo 2. Somatik hücre sayısı (SHS), Albümin (Alb), total protein (TP), trigliserit (TG), üre ve ürik asit (ÜA) düzeyleri arasındaki korelasyon ilişkisi

\begin{tabular}{lcccccc}
\hline & Alb & TP & TG & ÜRE & ÜA & SHS \\
\hline Alb & 1 & $0.772^{* *}$ & $-0,208$ & $0,530^{*}$ & $-0,376$ & $0.786^{* *}$ \\
TP & & 1 & 0,121 & $0.731^{* *}$ & $-0,249$ & 0.466 \\
TG & & & 1 & 0,041 & 0,439 & -0.241 \\
ÜRE & & & & 1 & $-0,457$ & 0.455 \\
ÜA & & & & & 1 & $-0.649^{* *}$ \\
SHS & & & & & & 1 \\
\hline
\end{tabular}

$*(\mathrm{P}<0,05), * *(\mathrm{P}<0,01)$

\section{Tartışma ve Sonuç}

Mastitis ülkemizde çok yaygın olarak görülmekte olup büyük ekonomik kayıplara neden olmaktadır. Özellikle subklinik mastitis diğer mastitislere oranla çok daha fazla görülmektedir. Erken teşhis edilmesi ve uygun olan tedavi yönteminin belirlenmesi büyük önem taşımaktadır. Mastitisin memeyi işgal eden patojenlere karşı inflamasyon reaksiyonu olmasından dolayı sütten somatik hücrelere akan immünreaktif hücrelerin ve süt somatik hücre sayılar1nın dramatik bir şekilde artması en önemli belirteç olarak bildirilmiştir $[11,46]$. Yaptığımız çalışmada subklinik mastitisli olan Anadolu mandalarının sütündeki SHS'deki artışın sağlıklı manda sütündeki SHS'ye göre istatistiksel olarak önemli düzeyde olduğunu belirledik $(\mathrm{P}<0.05)$. Subklinik mastitis, süt kompozisyonunda değişiklik ile bağışıklık sisteminin baskılanmasına neden olabilmektedir. Sığır sütündeki somatik hücre sayısının, meme sağlığ 1 ve süt kalitesinin bir göstergesi olduğu ve enflamatuar bir uyarandan sonra hücresel bağışıklık tepkisi ile ilişkili olabileceği bildirilmiştir [24].

SHS'si yüksek olan subklinik mastitisli manda sütlerinde total protein miktarının hafif arttığını ama bunun istatistiksel olarak önemli olmadığını belirledik $(\mathrm{P}>0.05)$. Subklinik mastitisin proteinlerin kandan süte geçişini kolaylaştıran kılcal geçirgenliği 
artırabileceği bildirilmiştir [5]. Bizim çalışmamıza paralel olarak Şahin ve Kaşıkcı (2014), esmer ineklerde SHS ile total protein arasinda önemli düzeyde pozitif bir korelasyon olduğunu bildirmiştir. Aynı şekilde Najafi ve ark. (2009), süt tankındaki hücre sayısı ile sütün protein içeriği arasında pozitif bir ilişkinin olduğunu, sütün protein fraksiyonlarının ilkbahar ve kış aylarında diğer aylara göre daha fazla değişim gösterdiğini bildirmişlerdir. Ayşan ve ark. (2011) ise süt ineklerinde SHS yüksek olanlarda total protein düzeyinin etkilenmediğini bildirmişlerdir.

Subklinik mastitisli manda sütlerinde albümin düzeyinin önemli düzeyde arttığını belirledik $(\mathrm{P}<0.05)$. Bizim çalışmamıza paralel olarak $[3,12,44,47]$, koyunlarda [22] ve keçilerde [23] subklinik mastitisli sütlerde albümin düzeyinin arttığ bildirilmiştir. Albümin sentezinin yapıldığ 1 başlıca yer karaciğer olup, az miktarda da olsa ekstrahepatik olarak meme bezi epitel hücrelerinde üretilmektedir [38]. Subklinik mastitis durumda sütteki albümin miktarının artması yangısal durumuna bağ11 olarak meme bezi epitel hücrelerinde sentezinin artmasından ve kan damarlarından sızıntı yaparak sütün içine geçmesinden kaynaklanabileceği düşünülmektedir.

Sütteki yağ oranı sütün fiyatlanmasını ve kalitesini etkileyen önemli unsurlardan biridir [29]. Yaptığımız çalışmada SHS yüksek olan sütlerde trigliserit düzeyinin etkilenerek azaldığ düzeyi ile süt yağı oranı arasında önemli düzeyde negatif korelasyon olduğunu belirledik $(\mathrm{P}<0.05)$. Bizim çalışmamıza paralel olarak mandalarda [1] ve ineklerde [31,32,35] bu ilişkinin önemli olduğu bildirilmiştir. Subklinik mastitis durumunda mandalarda süt serumunda yağ miktarının azalmasının meme bezinin sentez ve sekresyon yeteneğinin azalmasından kaynaklanabileceği düşünülmektedir.

Süt ve kandaki üre konsantrasyonu, protein alımı, protein türü ve protein enerjisinden kolayca etkilenmektedir [48]. Somatik hücre sayısı yüksek olanlar manda sütlerinde üre düzeyinin hafif yükseldiğini bunun istatistiksel olarak önemli olmad1ğını belirledik ( $\mathrm{P}>0.05)$. Bizim çalışmamıza paralel olarak SHS yüksek olan siyah alaca ineklerde üre düzeyinin hafif arttığı bunun istatistiksel olarak önemli olmadığı bildirilmiştir [7].
Ürik asit düşük molekül ağırlıklı hücre içi bir antioksidandır [20]. SHS yüksek olan subklinik mastitisli mandaların süt serumunda ürik asit düzeyinin sağlıklı manda sütüne göre azalmış olduğunu belirledik. İnek [14,39] ve keçi $[40,41]$ serumda ürik asit düzeyinin arttığ 1 bildirilmiștir. Ürik asit, antioksidant madde olup radikalleri yakalama özelliği bulunmakta olup SHS ile ürik asit arasında önemli düzeyde negatif korelasyon olduğu ( $\left.r=-0.649^{* *}\right)$, radikallerin artmasından dolayı süt serumunda ürik asit düzeyinin azalmış olabileceği düşünüldü.

Anadolu rrkı manda süt serumunda SHS yüksek olan subklinik mastitisli manda sütlerinin serumu sağlıklı olan mandalara göre süt kompozisyonunu değiștirdiği belirlendi. SHS ile trigliserit ve ürik asit arasında negatif korelasyon olduğu, albümin, total protein ve üre arasında ise pozitif korelasyon olduğu saptand1. Anadolu 1rk1 manda süt serumunda sınırlı sayıda çalışma bulunmaktadır. Yapılan bu çalışma ile elde edilen bu bulguların klinik ve laboratuvar bulguları ile birlikte subklinik mastitisi anlamada yardımcı olabileceği, tanısal ve prognostik olarak kullanılabileceği kanısına varılmıștır.

\section{Kaynaklar}

1. Ahmad T, Bilal M, Uallah S, Rahman ZU, Muhammad G, (2007). Impact of mastitis severity on mineral contents of buffalo milk. Pak J Agri Sci. 44, 176-178.

2. Ahmad S, Gaucher I, Rousseau F, Beaucher E, Piot M, Grongnet JF, Gaucheron F, (2008). Effects of acidification on physicochemical characteristics of buffalo milk: A comparison with cow's milk. Food Chem. 106, 11-17.

3. Alaçam E, Nizamlığlu M, Erganiş O, (1988). Ineklerde subklinik mastitislerin tanısı amacı ile süt ve kanda PGF2 alfa ile bazı mikrobiyolojik, hücresel ve biyokimyasal değerlerin araştırılması. Doğa T Vet ve Hay Derg. 12, 11-17.

4. Alaçam E, Tekeli T, Erganiş O, İzgi N. (1989). İnek ve mandalarda subklinik mastitislerin tanısı, etkenlerin izolasyonu ve bunlara karşı etkili antibiyotiklerin belirlenmesi. SÜ Vet Fak Derg. 5, 91- 101.

5. Andrei S, Adela P (2004). Vitamine, Enzime, Hormoni Analize Biochimice, Editura CLUSIUM, Cluj-Napoca, ISBN 973-555-434-8.

6. Ayaşan T, (2009). Süt ineklerinin beslenmesinde süt üre nitrojenin önemi. GOÜ Ziraat Fak Derg. 26, 27-33.

7. Ayaşan T, Hızlı H, Yazgan E, Kara U, Gök K, (2011). Somatik hücre sayıının süt üre nitrojen ile süt kompozisyonuna olan etkisi. Kafkas Univ Vet Fak Derg. 17, 659-662.

8. Baştan A, (2010). Ineklerde Meme Sağliğı ve Sorunları. Kardelen Ofset Matbaacılık, Ankara.

9. Blowey R, Edmondson P, (1995). Mastitis Control in Dairy Herds. Farming Press Books, Ipswich, United Kingtom. 
10. Butler WR, Calaman JJ Bean SW, (1996). Plasma and milk urea nitrogen in relation to pregnancy rate in lactating dairy cattle. J Anim Sci. 74, 858-865.

11. Bruckmaier RM, Weiss D, Wiedemann M, Schmitz S, Wendl G, (2004). Changes of physicochemical indicators during mastitis and the effects of milk ejection on their sensivity. J Dairy Res. 71, 316-321.

12. Coulon JB, Gasqui P, Barnouin J, Ollier A, Pradel P, Pomies $\mathrm{D}$, (2002). Effect of mastitis and related-germ on milk yield and composition during naturally-occurring udder infections in dairy cows. Anim Res. 51, 383-393.

13. Dairyman's Digest, (2009). What You Should Know About Somatic Cells. Winter issue.http://www.medvet. umontreal.ca/rcrmb/dynamiques/PDF AN/Management/ WhatShouldKnowSCC.pdf. Erişim Tarihi, 22.05.2018.

14. El-Deeb WM, (2018). Clinicobiochemical investigations of gangrenous mastitis in does: immunological responses and oxidative stress biomarkers. J Zhejiang Univ Sci B. 14, 33-9.

15. Fthenakis GC, El-Masannat ET, Booth JM, Jones JET, (1991). Somatic cell count of ewes' milk. Br Vet J. 147, $575-581$.

16. Gürbulak K, Canooğlu E, Abay M, Atabay O, Bekyurek T, (2009). Determination of subclinical mastitis in dairy cows by different methods. Kafkas Univ Vet Fak Derg. 15, 765770 .

17. Ishikawa $H$, Shimizu $T$, Hirano $H$, Saito $N$, Nakano $T$, (1982). Protein composition of whey from subclinical mastitis and effect of treatment with levamisole. J Dairy Sci. 65, 653-658.

18. Jonker JS, Kohn RA Hight J, (2002). Use of milk urea nitrogen to improve dairy cow diets. J Dairy Sci. 86, 939-946.

19. Kandemir FM, Yüksel MN, Özdemir N, Deveci H, (2013). A different approach to diagnosis of subclinical mastitis: milk different approach to diagnosis of subclinical mastitis: milk arginase activity arginase activity. Veterınarsk1 Arhıv. 83, 603-610.

20. Kassim SK, Elbeigermy M, Nasr GF, Khalil R, Nassar M, (2002). The role of interleukin-12, and tissue antioxidants in chronic sinusitis. Clin Biochem. 35, 369-375.

21. Kauffman AJ, St-Pierre NR, (2001). The relationship of milk urea nitrogen to urine nitrogen excretion in Holstein and Jersey cows. J Dairy Sci. 84, 2284-2294.

22. Leitner G, Chaffer M, Shamay A, Shapiro F, Merin U, Ezra E, Saran, A, Silanikove N (2004a). Changes in milk composition as affected by subclinical mastitis in sheep. J Dairy Sci. 87, 46-52.

23. Leitner G, Merin U, Silanikove N, (2004b). Changes in milk composition as affected by subclinical mastitis in goats. J Dairy Sci. 87, 1719-1726.

24. Lindmark-Mansson H, Akesson B, (2000). Antioxidative factors in milk. Br J 406 Nutr. 84, S103-S110.

25. Lindmark-Manssona H, Branning C, Alden G, Paulsson M, (2006). Relationship between somatic cell count, individual leukocyte populations and milk components. Int Dairy J. $16,717-727$.
26. Najafi MN, Mortazavi SA, Koocheki A, Khorami J, Rekik B, (2009). Fat and protein contents, acidity and somatic cell counts in bulk milk of holstein cows in the Khorasan Razavi province. Iran International Journal of Dairy Techn. 62, 19-26.

27. Ng-Kwai-Hang KF, Hayes JF, Moxley JE, Monardes HG (1985). Percentages of protein and nonprotein nitrogen with varying fat and somatic cells in bovine milk. J Dairy Sci. 68, 1257-1262.

28. Nourozi M, Moussavi AH, Abazari M Zadeh MR, (2010). Milk urea nitrogen and fertility in dairy farms. J Anim Vet Adv. 9, 1519-1525.

29. Olechnowicz J, Jaskowski JM, (2010). Impact of clinical lameness, calving season, parity, and month of lactation on milk, fat, protein, and lactose yields during early lactation of dairy cows. Bull Vet Inst Pulawy. 54, 605- 610.

30. Özyurtlu N, (2011). Ineklerde mastitisin ekonomik ve sağllk açısından önemi. Dicle Üniv Vet Fak Derg. 1, 36-38.

31. Paura L, Kairisha D, Jonkus D, (2002). Repeatability of milk productivity traits. Vet Zootech-Lith.19, 90-93.

32. Rajèeviè M, Potoènık K, Levstek J, (2003). Correlations between somatic cells count and milk composition with regard to the season. Agric Conspec Sci. 68, 221-226.

33. Raynal-Ljutovac K, Pirisi A, De Cremoux R, Gonzalo C (2007). Somatic cells of goat and sheep milk: analytical, sanitary, productive and technological aspects. Small Rumin Res 68,126-144

34. Roy B, Brahma B, Ghosh S, Pankaj PK, Mandal. G, (2011). Evaluation of milk urea concentration as useful indicator for dairy herd management: A review. Asian J Anim Vet Adv. 6, 1-19.

35. Sawa A, Piwczynski D, (2002). Somatic cell count and milk yield and composition in Black and White $x$ HolsteinFriezian cows. Med Weter.58, 636-640.

36. Schalm OW, Carrol EJ, Jain NC., (1971). Bovine Mastitis. Lea-Febiger Comp., Philadelphia.

37. Sederevicius A, Kabasinskiene A, Savickis S, Svedaite V, Makauskas S, (2008). Milk urea nitrogen as an important indicator of dairy cow: nutrition review. Vet Zootech-Lith. 44 (66).

38. Shamay A, Homans R, Fuerman Y, Levin I, Barash H, Silanikove N, Mabjeesh SJ (2005). Expression of albumin in non-hepatic tissues and its synthesis by the bovine mammary gland. J Dairy Sci. 88, 569-576.

39. Silanikove N, Shapiro F, Leitner G, (2007). Posttranslational ruling of xanthine oxidase activity in bovine milk by its substrates. Biochem Biophys Res Commun. 363, 561-565.

40. Silanikove N, Rauch-Cohen A, Shapiro F, Arieli A, Merin U, Leitner G, (2012). Lipopolysaccharide challenge of the mammary gland in cows induces nitrosative stress that impaired milk oxidative stability. Animal. 6, 1451-1459.

41. Silanikove N, Merin U, Shapiro F, Leitner G, (2014). Subclinical mastitis in goats is associated with upregulation of nitric oxide derived oxidative stress that causes reduction of milk antioxidative properties and impeirment of its quality. J Dairy Sci. 97, 3449-55. 
42. Şahin A, Kaşıkçı M, (2014). Esmer ineklerde somatik hücre sayısı ve bazı çiğ süt parametreleri arasındaki ilişkilerin belirlenmesi. TURJAF. 2, 220-223.

43. Şahin M, Çolak A, Otlu S, Aydın F, Genç O, Güler MA, Oral H, (1997). Kars yöresi ithal Simental ineklerinde subklinik ve klinik mastitislerin görülme oranlart ve etkili antibiyotiklerin belirlenmesi. Kafkas Üniv Vet Fak Derg. 3, 49-55.

44. Urech, E, Puhan Z, Schallibaum M, (1999). Changes in milk protein fraction as affected by subclinical mastitis. J Dairy Sci. 82, 2402-2411.

45. Varrichio ML, Di Francia A, Masucci F, Romano R Proto V, (2007). Fatty acid composition of Mediterranean buffalo milk fat. Italian J Animal Sci. 6, 509-511.
46. Viguier C, Arora S, Gilmartin N, Welbeck K, O'Kennedy $\mathrm{R}$, (2009). Mastitis detection: current trends and future perspectives. Trends Biotechnol. 27, 486-493.

47. Vijayalakshmi P, Prathaban S, Dhanapalan P, (2001). Comparative study on the efficacy of diagnostic tests in the field diagnosis of bovine mastitis. Indian Vet J. 78, 4-6.

48. Whitaker DA, Kelly JM, Eayres HF, (1995). Assessing dairy cow diets through milk urea tests. Vet Rec. 136, 179-180.

49. Yüksel M, Kandemir FM, Deveci H, Özdemir N (2009). The serum ALP, ALT and glucose levels of healthy and subclinically mastitic cows. J Vet Sci Ataturk University. 4, 163-168. 